\title{
Glyceollins inhibit platelet-derived growth factor-mediated human arterial smooth muscle cell proliferation and migration
}

\author{
Hyo Jung Kim ${ }^{1}$, Byung-Yoon $\mathrm{Cha}^{2}$, Bongkeun $\mathrm{Choi}^{3}$, Ji Sun $\mathrm{Lim}^{1}$, Je-Tae Woo ${ }^{2 *}$ and Jong-Sang Kim ${ }^{1 *}$ \\ ${ }^{1}$ School of Life and Food Sciences, College of Agriculture and Life Sciences, Kyungpook National University, \\ Deagu 702-701, Republic of Korea \\ ${ }^{2}$ Research Institute for Biological Functions, Chubu University, Japan \\ ${ }^{3}$ Graduate School of Bioagricultural Sciences and School of Agricultural Sciences, Nagoya University, Japan
}

(Received 24 November 2010 - Revised 30 March 2011 - Accepted 31 March 2011 - First published online 29 June 2011)

\section{Abstract}

Platelet-derived growth factor (PDGF)-BB can induce abnormal proliferation and migration of vascular smooth muscle cells (VSMC) that are involved in the development of CVD. In our preliminary study, phytoalexin glyceollins (glyceollins I, II and III) isolated from soyabean seeds cultured with Aspergillus sojae showed strong antioxidant and anti-inflammatory activity. Since antioxidants showed beneficial effects on chronic inflammatory diseases, the purpose of the present study was to examine the effects of glyceollins on PDGF-induced proliferation and migration in human aortic smooth muscle cells (HASMC). Incubation of resting HASMC with glyceollins for $24 \mathrm{~h}$ significantly diminished PDGF-increased cell number and DNA synthesis in a dose-dependent manner without any cytotoxicity. In addition to blocking of the PDGF-inducible progression through the $G_{0} / G_{1}$ to the $S$ phase of the cell cycle, glyceollins down-regulated the expression of cyclindependent kinase (CDK)2 and cyclin D1, and up-regulated the expression of CDK inhibitors such as p2 $7^{\text {kip } 1}$ and p53.Glyceollins also effectively inhibited reactive oxygen species generation and phosphorylation of PDGF receptor- $\beta$, phospholipase C $\gamma 1$, Akt and extracellular signal-regulated kinase $1 / 2$ by PDGF stimulation. Furthermore, glyceollins were found to inhibit PDGF-induced dissociation of actin filaments and cell migration. Thus, the results suggest that glyceollins could become a potent therapeutic agent for regulating VSMC-associated vascular disease such as atherosclerosis and restenosis after angioplasty.

Key words: Glyceollins: Smooth muscle cells: Platelet-derived growth factor-BB: Platelet-derived growth factor signal pathway: Proliferation: Migration

Accumulation of vascular smooth muscle cells (VSMC) is a key event in the formation and development of lesions of atherosclerosis. The excessive accumulation of VSMC is due to a combination of directed migration from the media into the intima of the artery accompanied by proliferation and possibly decreased apoptosis. The proliferation and migration of VSMC are involved in vascular remodelling and intimal lesion formation, and these can be induced by various growth factors, such as platelet-derived growth factor (PDGF) or basic fibroblast growth factor ${ }^{(1-4)}$. PDGF is expressed by platelets, smooth muscle cells, endothelial cells and macrophages, and PDGF-BB among the PDGF isomers is a potent inducer of VSMC proliferation and migration compared with PDGF-AA and PDGF-AB ${ }^{(2-4)}$.
Although the role of PDGF on vascular biology is important, the mechanisms related to PDGF-stimulated smooth muscle cell proliferation and migration have not been fully elucidated. Several studies have reported that PDGF interferes with actin filament assembly and causes marked up-regulation of PDGF receptor (PDGFR) expression after injury to the vessel wall $^{(5)}$. In an animal model, infusion of PDGF-BB promoted intimal thickening and promoted VSMC migration from the media to intima ${ }^{(6)}$, and the blocking of PDGFR decreased in smooth muscle cell growth and neointimal formation in response to injury ${ }^{(7)}$. Some studies also showed that activation of mitogen-activated protein kinase (MAPK) (extracellular signal-regulated kinases; ERK1/2) is implicated in the PDGFmediated DNA synthesis and proliferation process ${ }^{(8)}$, and the

Abbreviations: AM, acetoxymethyl ester; CDK, cyclin-dependent kinase; DMSO, dimethylsulfoxide; ERK, extracellular signal-regulated kinase; HASMC, human aortic smooth muscle cells; MAPK, mitogen-activated protein kinase; PDGF, platelet-derived growth factor; PDGFR, platelet-derived growth factor receptor; PI3K, phosphoinositide 3-kinase; PLC, phospholipase C; pRB, retinoblastoma protein; ROS, reactive oxygen species; VSMC, vascular smooth muscle cells. 
ability of the PDGF to activate phospholipase C (PLC) $\gamma 1$ and phosphoinositide 3-kinase (PI3K)/Akt correlated with its ability to induce migration of smooth muscle cells rather than DNA synthesis and proliferation ${ }^{(9)}$. Furthermore, PDGFR transports its signal into the intracellular space by the generation of reactive oxygen species (ROS). For instance, $\mathrm{H}_{2} \mathrm{O}_{2}$ was related to stimulation of the phosphorylation of ERK1/2 in PDGF-stimulated VSMC proliferation ${ }^{(10)}$.

Isoflavone-rich soya foods, soya protein isolate and isoflavone extracts have been reported to improve cognitive performance $^{(11,12)}$, menopausal symptoms ${ }^{(13,14)}$, bone health ${ }^{(15)}$, hypertension $^{(16)}$ as well as prevent lipid peroxidation ${ }^{(17,18)}$, and breast ${ }^{(19)}$ and prostate cancers ${ }^{(20,21)}$. In addition, several studies demonstrated that soya protein with isoflavones exhibited atheroprotective effects by increasing HDL-cholesterol, reducing vascular inflammation and platelet aggregation, and inhibiting human aortic smooth muscle cell (HASMC) proliferation $^{(22)}$. Isoflavones scavenge free radicals that are involved in platelet stimulation, suggesting novel anti-aggregatory mechanism of isoflavones ${ }^{(23)}$. Furthermore, soya-isoflavone supplementation reduced NF- $\kappa \mathrm{B}$ activation induced by TNF- $\alpha$ in human lymphocytes ${ }^{(24)}$. Genistein, in particular, activates endothelial NO synthase (eNOS) by stimulation of cAMP production, leading to the phosphorylation of eNOS. These results indicate that isoflavones have specific pathways by which these oestrogen-like components induce vasodilatory effects $^{(25)}$. Treatment of human umbilical vein endothelial cells (HUVEC) with genistein resulted in a dose-dependent inhibition of TNF- $\alpha$-induced expression of adhesion molecules such as E-selectin, vascular cell adhesion molecule-1 and inter-cellular adhesion molecule- ${ }^{(26)}$. Genistein and daidzein not only inhibited NO production via suppression of inducible $\mathrm{NO}$ synthase in activated macrophages but also reduced monocyte chemotactic protein (MCP)-1 secretion ${ }^{(27)}$.

Glyceollins, which are synthesised from daidzein in soyabeans cultured with Aspergillus sojae, have been shown to have cancer-preventive properties ${ }^{(28,29)}$ and represent another group of phytoalexins whose biosynthesis is increased in soyabean in response to various stress signals such as fungal infection $^{(30,31)}$. Flavonoids are a group of widely distributed plant polyphenols having antioxidant activity. As glyceollins have similar structure to other soyabean isoflavonoids (Fig. 1), it is presumed that they share common physiological properties. Research in our laboratory showed a marked oestrogenic activity of glyceollins in vitro on oestrogen receptor signalling ${ }^{(32)}$. Moreover, our recent preliminary studies show that glyceollins have anti-inflammatory and antioxidant activity.
In the present study, the anti-atherosclerotic effects of glyceollins derived from soyabean elicited with fungi were evaluated and found that these compounds can inhibit the PDGF-stimulated proliferation and migration of HASMC.

\section{Experimental methods}

\section{Preparation of glyceollins}

A mixture of glyceollins I, II and III was isolated according to the method described previously ${ }^{(32)}$. Briefly, glyceollin-rich extract was prepared by inoculation of soyabean seed with A. sojae in a dark chamber at $26^{\circ} \mathrm{C}$ for $3 \mathrm{~d}$. After homogenisation in $80 \%$ aqueous ethanol and incubation, the filtered extract was freeze-dried. The ethyl acetate soluble fraction of the crude extract was subjected to silica gel column chromatography. One fraction was subjected to TLC and HPLC to confirm existence of glyceollins, and then the fraction was evaporated under reduced pressure.

\section{Cell culture}

HASMC were obtained from Cascade Biologics, Inc. (Portland, OR, USA). For routine maintenance, cells were grown in Dulbecco's modified Eagle's medium (DMEM; Gibco, Grand Island, NY, USA) supplemented with 10\% heat-inactivated fetal bovine serum at $37^{\circ} \mathrm{C}$ in an atmosphere of $5 \% \mathrm{CO}_{2}-$ $95 \%$ air under saturating humidity and passaged every week (1:4 split ratio) by trypsinisation with $0.25 \%$ trypsin-0.02\% EDTA sodium salt solution (Thermo Fisher Scientific Inc., Waltham, MA, USA).

\section{Cell proliferation assay}

The experimental procedures were performed according to previously described methods with some modifications. Briefly, HASMC were trypsinised and plated into ninety-sixwell plates with the DMEM at an initial concentration of $1 \times 10^{4}$ cells per well and incubated in an atmosphere consisting of $5 \% \mathrm{CO}_{2}$ in air at $37^{\circ} \mathrm{C}$ for $24 \mathrm{~h}$. Then the medium was removed and replaced by the medium containing a range of concentrations of test compounds in serum-free DMEM. The bioassay was terminated on day 1 by removing the medium from the wells, and adding 3-[4,5-dimethyl-thiazol-2-yl]-2,5diphenyltetrazolium bromide (MTT) solution $(0.5 \mathrm{mg} / \mathrm{ml}$ in phenol red-free culture medium). After $2 \mathrm{~h}$, the solution was removed and $200 \mu \mathrm{l}$ dimethylsulfoxide (DMSO) were added. After $10 \mathrm{~min}$, the absorbance was determined at $540 \mathrm{~nm}$ by a (a)

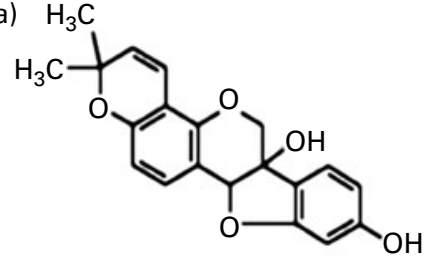

(b)

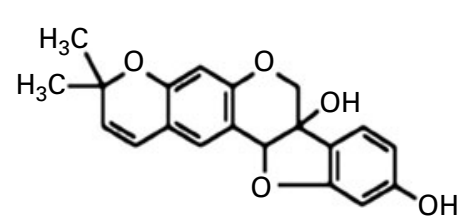

(c)

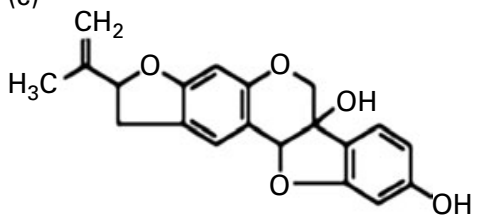

Fig. 1. Molecular structures of glyceollins I (a), II (b) and III (c). 
microplate reader (Tecan, Grödig, Austria). The cell proliferation of each group was calculated as the relative absorbance of treatment group compared with control.

\section{Synthesis assay}

Thymidine incorporation experiments were carried out according to a previously described method ${ }^{(33)}$. The HASMC were cultured until they reached about $40 \%$ confluence. The culture medium was changed with serum-free medium and incubated for $24 \mathrm{~h}$. The serum-deprived cells were then pre-incubated with glyceollins for $24 \mathrm{~h}$ and stimulated with/ without PDGF or with/without glyceollins for $20 \mathrm{~h}$. After the incubation, $1 \mu \mathrm{Ci} / \mathrm{ml}(37000 \mathrm{~Bq})$ of $\left[{ }^{3} \mathrm{H}\right]$ thymidine was added to the cultures and incubated for $4 \mathrm{~h}$ at $37^{\circ} \mathrm{C}$. The cells were harvested using a Universal Harvester (Perkin Elmer, Waltham, MA, USA), and transferred to a GF/C filter (Perkin Elmer). The filter was dried and the level of radioactivity was determined using a Microplated Scintillation and Luminescence Counter-Topcount NXT (Perkin Elmer). The values were calculated from absolute counts to a percentage of the control to allow comparison between the experimental groups.

\section{Cell cycle analysis}

Cell cycle progression analysis was measured as described previously ${ }^{(34)}$. HASMC were seeded in six-well plates at $2 \times 10^{5}$ cells/well and incubated until the cell density reached $80 \%$. Then the medium was replaced with serum-free medium and incubated for $24 \mathrm{~h}$. The cells were then pre-incubated with glyceollins for $24 \mathrm{~h}$ and stimulated with/without PDGF or with/without glyceollins for $24 \mathrm{~h}$. The HASMC were harvested, re-suspended in $70 \%$ ethanol, and incubated at $-20^{\circ} \mathrm{C}$ for $4 \mathrm{~h}$. The fixed cells were washed twice with PBS, and incubated at $37^{\circ} \mathrm{C}$ for $60 \mathrm{~min}$ using a solution containing DNAse-free RNAse $(200 \mu \mathrm{g} / \mathrm{ml})$. After incubation, the cells were stained with propidium iodide $(50 \mu \mathrm{g} / \mathrm{ml})$ at $4{ }^{\circ} \mathrm{C}$ for $30 \mathrm{~min}$ and subjected to a flow cytometric analysis (Becton Dickinson, Franklin Lakes, NJ, USA).

\section{Migration assay}

Cell migration was measured using a modified Boyden transwell chamber (twenty-four-well plate) assay as described in our previous study ${ }^{(33)}$. Starved cells were trypsinised and cell suspension in basal medium $\left(500 \mu \mathrm{l}, 5 \times 10^{4}\right.$ cells/well) seeded in the upper chamber. Then, $760 \mu \mathrm{l}$ of serum free medium with or without experimental compounds were added to the lower chamber. After incubation for $24 \mathrm{~h}$, the cells were labelled by fluorescence dye calcein-acetoxymethyl ester (AM) $(4 \mu \mathrm{g} / \mathrm{ml})$. The cells migrated to the lower chamber were measured using a fluorescence microplate reader at $485 \mathrm{~nm}$ excitation and $530 \mathrm{~nm}$ emission wavelengths. Each treatment was repeated in three independent transwells.

\section{Wound healing assay}

When the HASMC had grown to $80 \%$ confluence in the eightwell plate, a scratch was made with a sterile cell scraper as described in a previous study ${ }^{(35)}$. Cells were washed with PBS twice, were incubated for $18 \mathrm{~h}$ with or without glyceollins $(3 \mu \mathrm{g} / \mathrm{ml})$ in the presence or absence of PDGF $(20 \mathrm{ng} / \mathrm{ml})$ in serum-free medium, stained with haematoxylin and eosin. The plates were photographed and the wound width was calculated by a microruler.

\section{Dichlorofluorescein assay}

Oxidative stress was quantified in cells by the dichlorofluorescein (DCF) assay according to the method described by Wang $\&$ Joseph $^{(36)}$, with slight modifications. Briefly, HASMC were seeded into black-bottom ninety-six-well plates, and cultured for $24 \mathrm{~h}$. After attachment, plates were washed with PBS and the cells were incubated with $\mathrm{H}_{2} \mathrm{O}_{2}(1000 \mu \mathrm{M})$ for $2 \mathrm{~h}$ before treatment with increasing concentrations of each generation of experimental compounds prepared in serum-free media for $24 \mathrm{~h}$. The stimulated cells were washed with PBS and incubated for $30 \mathrm{~min}$ with dichlorofluoresceindiacetate, dissolved in DMSO (final concentration $50 \mu \mathrm{m}$ ). Fluorescence was measured at 0 and $40 \mathrm{~min}$ using excitation and emission wavelengths of 485 and $535 \mathrm{~nm}$, in a Tecan microplate reader (Tecan). All dye and oxidant incubations, washing steps and fluorimetric determination were performed in a dark room. The intensity of fluorescence was calculated as $\left(\left(\mathrm{F}_{40 \mathrm{~min}}-\right.\right.$ $\left.\left.\mathrm{F}_{0 \text { min }}\right) / \mathrm{F}_{0 \text { min }}\right) \times 100$ as described. Results are expressed as relative intensity of fluorescence (as $\%$ of $\mathrm{H}_{2} \mathrm{O}_{2}$ control).

\section{Dihydroethidium assay}

The production of superoxide anion in HASMC was measured using the oxidation-sensitive dye dihydriethidium ${ }^{(37)}$. HASMC were stained by incubation for $30 \mathrm{~min}$ at $37^{\circ} \mathrm{C}$ with $10 \mu \mathrm{m}$-dihydriethidium (Sigma). The cells were washed with PBS twice, and photographed using a Nikon Eclipse 80i fluorescence microscope and a Nikon Digital Sight DS-Fi1c camera (Nikon, Tokyo, Japan).

\section{Western blotting}

HASMC were homogenised in pre-cooled radio-immunoprecipitation assay (RIPA) buffer ( $\mathrm{pH} 7 \cdot 4)$ containing 2-amino-2hydroxymethyl-propane-1,3-diol (Tris)- $\mathrm{HCl} \quad(50 \mathrm{~mm}), \mathrm{NaCl}$ $(150 \mathrm{~mm})$, EDTA (1 mm), Triton-X (1\%), sodium deoxycholate (0.5\%) and SDS (0.1\%). The homogenates were cleared by centrifugation at $9000 \mathrm{rpm}$ for $5 \mathrm{~min}$ at $4^{\circ} \mathrm{C}$, and the supernatant fractions were denatured in sample buffer for $5 \mathrm{~min}$ at $95^{\circ} \mathrm{C}$. Proteins were separated by electrophoresis on a $10 \%$ SDS-polyacrylamide gel for $1.5 \mathrm{~h}$ at $70-150 \mathrm{~V}$ and transferred onto nitrocellulose membranes (Amersham Biosciences, Freiburg, Germany) for $2 \mathrm{~h}$ at $250 \mathrm{~mA}$. Membranes were incubated with antibodies to phosphorylated PDGFR- $\beta$, PDGFR- $\beta$, phosphorylated Akt, Akt, phosphorylated PLC $\gamma$, PLC $\gamma$, phosphorylated MAPKinases, MAPKinases, cyclin-dependent kinase (CDK)1, CDK4, cyclin D1, cyclin E, p2 $7^{\mathrm{kip} 1}, \mathrm{p} 21^{\mathrm{cip} 1}, \mathrm{p} 53$ and 
$\beta$-actin at dilutions of 1:1000 overnight at $4^{\circ} \mathrm{C}$. The bands were detected using a chemiluminescence kit (Pierce, Chester, Cheshire, UK). Densitometry analysis was performed with Lab Image software (Scion Corp., Walkerville, MD, USA).

\section{Statistical analysis}

All values are expressed as mean values and standard deviations. For statistical significance, unpaired Student's $t$ tests were used. A significant difference was indicated at $P<0.05$.

\section{Results}

Effects of glyceollins on human aortic smooth muscle cell proliferation and platelet-derived growth factorstimulated cycle progression

When HASMC were stimulated by PDGF-BB $(20 \mathrm{ng} / \mathrm{ml})$, the number of cells increased by approximately 34.5\% compared the non-stimulated group. Treatment with glyceollins $(0.3-3 \mu \mathrm{g} / \mathrm{ml})$ for $24 \mathrm{~h}$ in PDGF-stimulated HASMC resulted in a significant decrease in cell number without any cytotoxicity. The ratio of inhibition was 13.6 (SD 2.3), 16.7 (SD 4.1) and 30.7 (SD 4.6 ) $\%$ at $0.3,1.5$ and $3 \mu \mathrm{g} / \mathrm{ml}$, respectively (Fig. 2(a)). There was no significant change in cell morphology in cultures treated with PDGF plus glyceollins (Fig. 2(c)).

The effect of glyceollins on DNA synthesis was assayed by $\left[{ }^{3} \mathrm{H}\right]$ thymidine incorporation. As shown in Fig. 2(b), PDGF at $20 \mathrm{ng} / \mathrm{ml}$ led to a significant increase in $\left[{ }^{3} \mathrm{H}\right]$ thymidine incorporation that corresponded to approximately 4.2-fold of non-stimulated cells. Glyceollins effectively inhibited the PDGF-induced $\left[{ }^{3} \mathrm{H}\right]$ thymidine incorporation into DNA in a dose-dependent manner. The inhibition percentage of glyceollins was about 27.3 (SD 6.0), 52.6 (SD 4.7) and $41 \cdot 0$ (SD 2.7 ) $\%$ at $0.3,1.5$ and $3 \mu \mathrm{g} / \mathrm{ml}$, respectively.

The DNA content was analysed by propidium iodide staining to investigate the effect of glyceollins on cell cycle progression in HASMC. PDGF-BB $(20 \mathrm{ng} / \mathrm{ml})$ induced an increase in the $\mathrm{S}$ phase from $2 \cdot 3 \%$ to $18 \cdot 1 \%$ compared with the control. Glyceollins dose-dependently decreased accumulation at the S phase to $11.3 \%$ at $0.3 \mu \mathrm{g} / \mathrm{ml}, 8.2 \%$ at $1.5 \mu \mathrm{g} / \mathrm{ml}$ and $5.6 \%$ at $3 \mu \mathrm{g} / \mathrm{ml}$ in PDGF-treated cells in a dose-dependent fashion. These results indicate that glyceollins were effective in arresting PDGF-stimulated cell cycle progression in HASMC.

\section{Effects of glyceollins on the expression of cell cycle-related proteins}

Cell cycle progression is tightly regulated through a complex network of positive and negative cell cycle-regulatory molecules such as CDK and cyclins. To investigate whether inhibition of proliferation by glyceollins involves the regulation of cell cycle-related proteins, we assessed the expression of $\mathrm{G}_{1}$-checkpoint proteins in glyceollin-treated cell cycle arrest. As shown in Fig. 3(c), glyceollins significantly decreased the level of CDK2 and cyclin E, but did not change the levels of
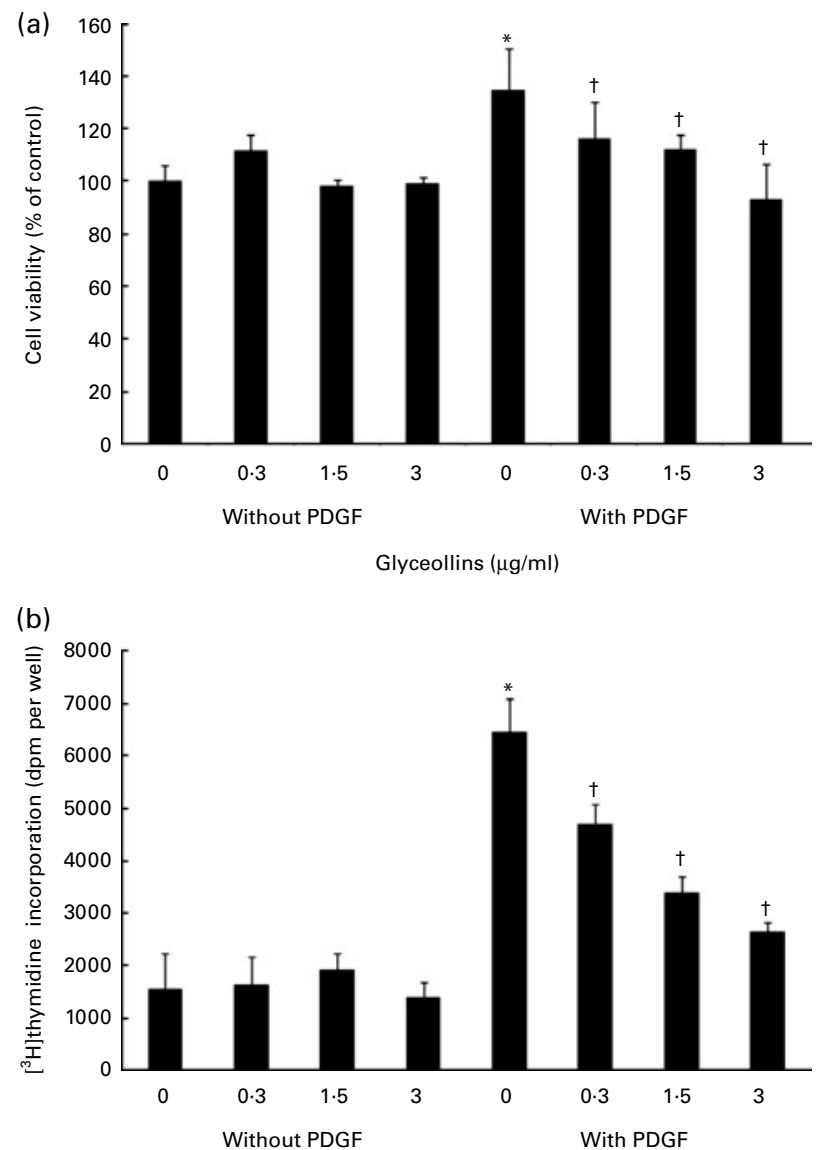

(c)
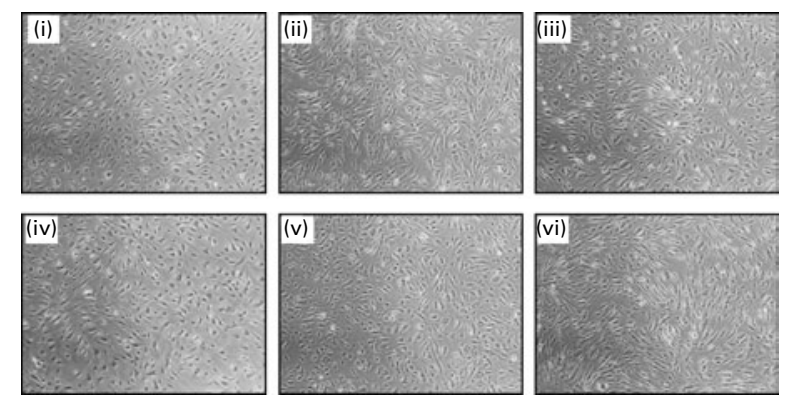

Fig. 2. Effects of glyceollins on platelet-derived growth factor (PDGF)induced human aortic smooth muscle cell (HASMC) proliferation. HASMC were treated with or without glyceollins $(3 \mu \mathrm{g} / \mathrm{ml})$ in the presence or absence of PDGF $(20 \mathrm{ng} / \mathrm{ml})$ after pre-incubation with or without glyceollins for $24 \mathrm{~h}$. After incubation for $20-24 \mathrm{~h}$, the cells were processed for the 3-[4,5dimethyl-thiazol-2-yl]-2,5-diphenyltetrazolium bromide (MTT) assay (a) or $\left[{ }^{3} \mathrm{H}\right]$ thymidine incorporation (b) as described in the Materials and methods section. Values are means of three separate experiments, with standard deviations represented by vertical bars. ${ }^{*}$ Mean value was significantly different from that without PDGF $(P<0.05)$. $†$ Mean value was significantly different from that in the absence of glyceollins $(P<0.05)$. Morphology of cells cultured under different conditions was observed by microscopy (c): (i) control; (ii) glyceollins ( $3 \mu \mathrm{g} / \mathrm{ml})$; (iii) PDGF; (iv) PDGF + glyceollins $(0.3 \mu \mathrm{g} / \mathrm{ml})$; (v) PDGF + glyceollins (1.5 $\mu \mathrm{g} / \mathrm{ml})$; (vi) PDGF + glyceollins $(3 \mu \mathrm{g} / \mathrm{ml})$. Magnification $40 \times$.

CDK4 and cyclin D. Therefore, these findings suggest that glyceollins affect the transition of HASMC from the $G_{1}$ to the $S$ phase, together with its inhibitory effects on HASMC proliferation. The effect of glyceollins on the expression level of CDK 
(a)

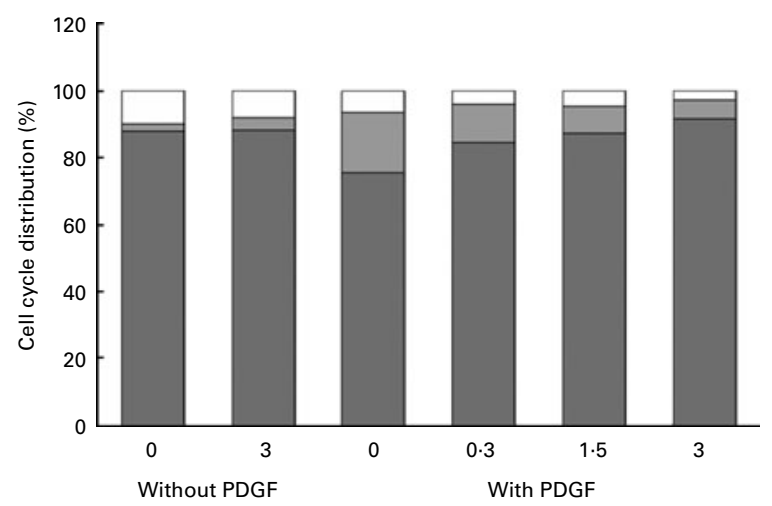

Glyceollins ( $\mu \mathrm{gml})$

(b)
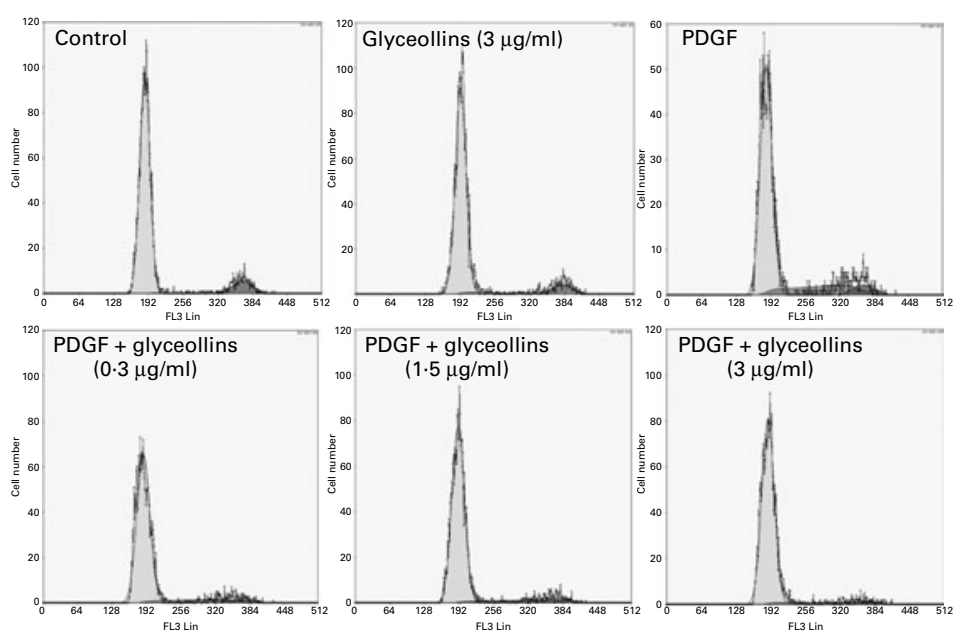

(c)

$$
\text { CDK4 }
$$

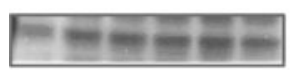

Cyclin D1

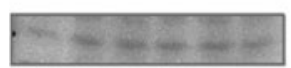

CDK2
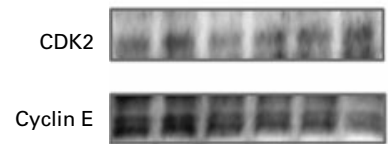

PDGF $(20 \mathrm{ng} / \mathrm{ml})$

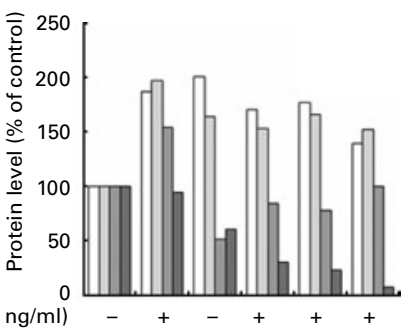

p27

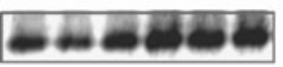

p21

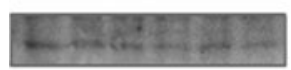

p53

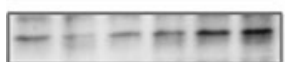

$\beta$-Actin

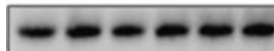

PDGF $(20 \mathrm{ng} / \mathrm{ml})$

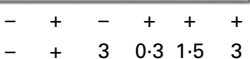

Glyceollins $(\mu \mathrm{g} / \mathrm{ml})$ - +30.31 .53$

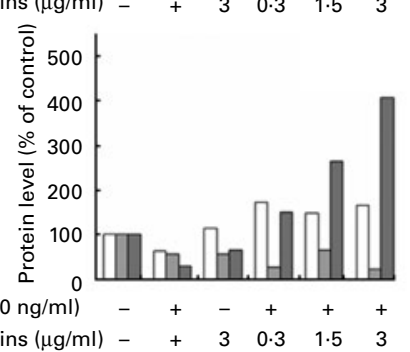

Fig. 3. (a) Effect of glyceollins on cell cycle progression in human aortic smooth muscle cells (HASMC) stimulated by platelet-derived growth factor (PDGF). HASMC were treated as described in Fig. 2(a). ( $\square$ ), $\mathrm{G}_{2} / \mathrm{M} ;(\square)$, $\mathrm{S} ;(\square), \mathrm{G}_{0} / \mathrm{G}_{1}$. (b) Representative DNA histograms of propidium iodide fluorescence in cells as assessed by flow cytometry. The profiles are representative examples of experiments measured in the presence of PDGF, together with different doses of glyceollins $(0.3,1.5,3 \mu \mathrm{g} / \mathrm{ml})$. DNA histograms for untreated control and for cells treated with PDGF or glyceollins alone are also shown for reference. (c) For evaluation of the expression of protein related to cell cycle progression, whole cell extracts $(20 \mu \mathrm{g})$ were subjected to Western blot analysis for phosphorylation of cyclindependent kinase (CDK)4, cyclin D1, CDK2, cyclin E, p21, p27, p53 or $\beta$-actin. Upper histogram: ( $\square$ ), CDK4: $\beta$-actin; ( $\square$ ), cyclin D1: $\beta$-actin; ( $\square$ ), CDK2: $\beta$-actin; $(\square)$, cyclin E: $\beta$-actin. Lower histogram: $(\square)$, p27: $\beta$-actin; ( $\square)$, p21: $\beta$-actin; ( $\square$ ), p53: $\beta$-actin. 
inhibitor $\mathrm{p} 27^{\mathrm{kip} 1}$ and $\mathrm{p} 53$ was further clarified. The protein levels of $\mathrm{p} 27^{\mathrm{kip} 1}$ and $\mathrm{p} 53$ were reduced at $24 \mathrm{~h}$ after stimulation by PDGF, while they were significantly enhanced in HASMC treated with glyceollins in a dose-dependent manner. The expression of $\mathrm{p} 21^{\mathrm{cip} 1}$ protein was not influenced by PDGF or glyceollins.

\section{Effects of glyceollins on signalling pathway related to platelet-derived growth factor}

PDGF-induced expression of proteins such as PDGFR- $\beta$, PLC $\gamma 1$ and Akt was detected to investigate the inhibitory mechanism of glyceollins on the signal transduction pathway of PDGF for HASMC proliferation and migration. HASMC were stimulated with PDGF-BB $(20 \mathrm{ng} / \mathrm{ml})$ for $15 \mathrm{~min}$, which caused obvious phosphorylation of PDGFR- $\beta$, PLC $\gamma 1$, Akt

(a)

(b)

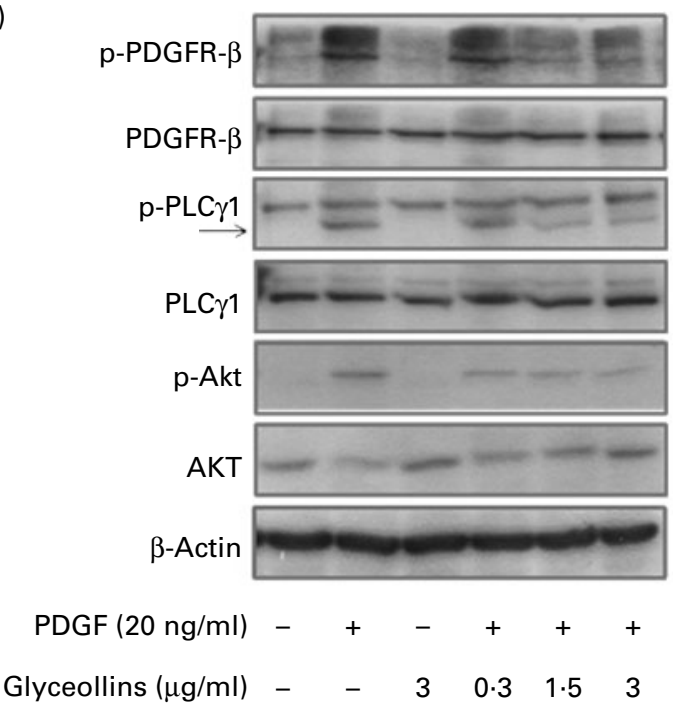

and ERK1/2, and the increased phosphorylation was suppressed by glyceollins of various concentrations, suggesting that the anti-proliferative effect of glyceollins was implicated in early signal transduction by PDGF (Fig. 4(a)).

Since PDGF is capable of inducing the activation of MAPK for VSMC proliferation ${ }^{(9)}$, we investigated the effects of glyceollins on the PDGF signalling pathway by measuring the phosphorylation levels of MAPK including p38, c-Jun N-terminal protein kinase (JNK) and ERK1/2 with Western blotting (Fig. 4(b)) in HASMC. As shown in Fig. 4(b), PDGF substantially increased ERK1/2 phosphorylation, but not p38 and JNK phosphorylation, at $15 \mathrm{~min}$ after stimulation, whereas cells incubated with glyceollins at various concentrations $(0.3,1.5$ and $3 \mu \mathrm{g} / \mathrm{ml})$ diminished the ERK1/2 phosphorylation. Unlike ERK1/2, JNK and p38 phosphorylation were not affected by glyceollins, indicating that

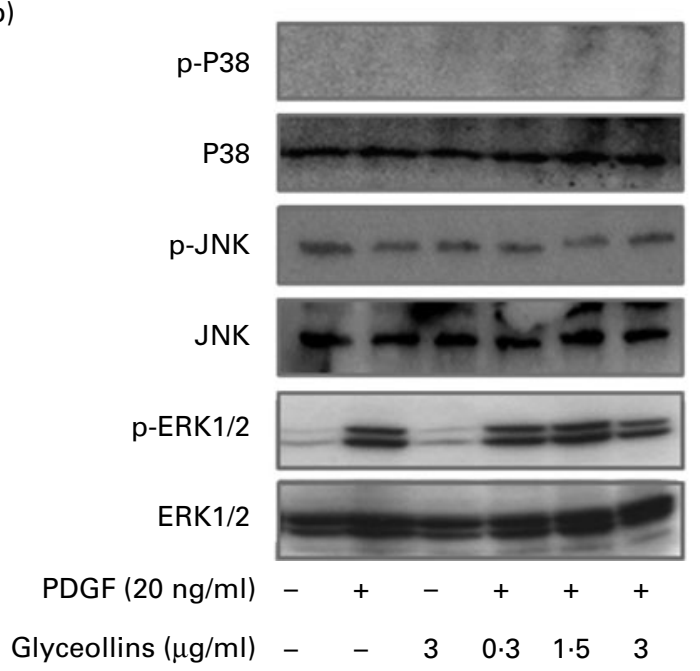

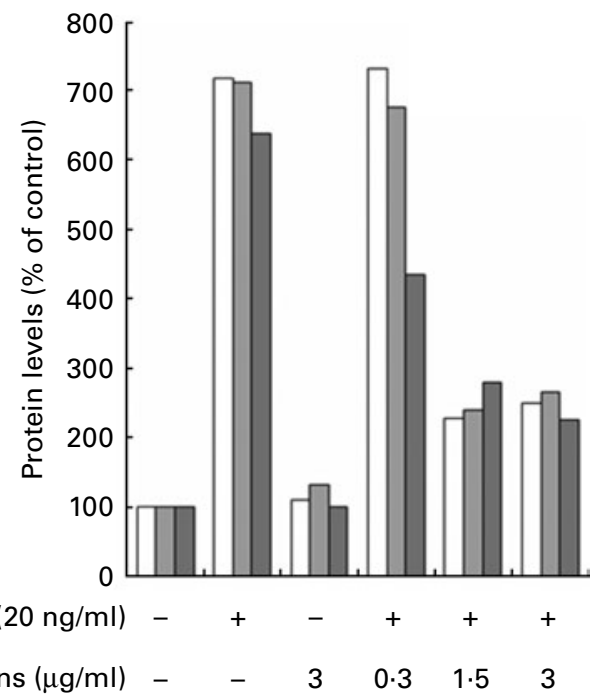

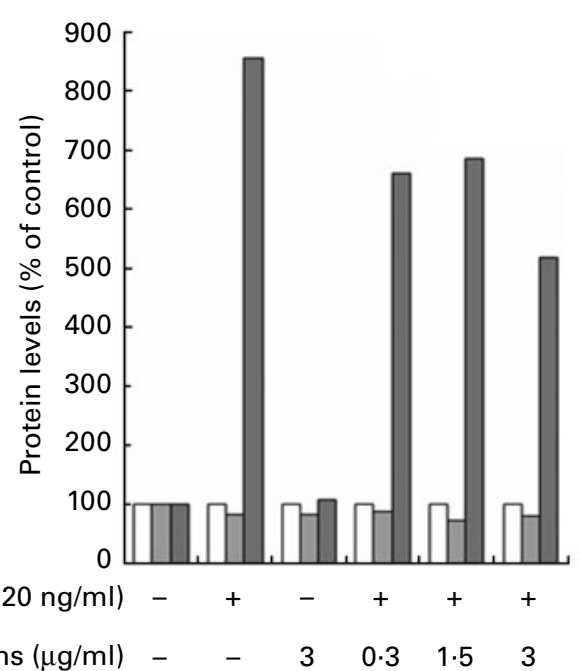

Fig. 4. Effects of glyceollins on the platelet-derived growth factor (PDGF) signalling pathway. Western blot of phosphorylation of PDGF receptor (PDGFR)- $\beta$, phospholipase (PLC) $\gamma 1$ and Akt (a) and activation of mitogen-activated protein kinase (b) was performed when human aortic smooth muscle cells were treated with glyceollins $(3 \mu \mathrm{g} / \mathrm{ml})$ with or without PDGF-BB $(20 \mathrm{ng} / \mathrm{ml})$ for $15 \mathrm{~min}$ after pre-incubation with glyceollins for $24 \mathrm{~h}$. (a): ( $\square$ ), Phosphorylated PDGFR- $\beta$ :PDGFR- $\beta$; ( $\square$ ),

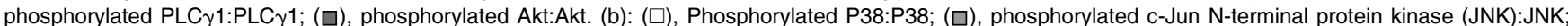
$(\square)$, phosphorylated extracellular signal-regulated kinase (ERK):ERK. 
glyceollins influence ERK1/2 signalling pathways on PDGFstimulated HASMC.

\section{Role of reactive oxygen species on glyceollin-mediated inhibition of intracellular signalling transduction by platelet-derived growth factor}

Various ROS are associated with PDGFR-mediated signalling events $^{(10,38)}$ and can affect the activation of MAPK ${ }^{(39)}$. To confirm the role of ROS in glyceollin-mediated inhibition of the PDGF signalling pathway, dichlorofluorescein and dihydroethidium (DHE) assays were carried out. The results revealed that PDGF-BB $(20 \mathrm{ng} / \mathrm{ml})$ induced ROS formation up to $2 \cdot 1$-fold compared with DMSO-treated cells as control, whereas treatment with glyceollins $(0.3,1.5$ and $3 \mu \mathrm{g} / \mathrm{ml})$ markedly inhibited the reaction to 10.5 (SD 1.2), 12.3 (SD 1.2) and $25 \cdot 1$ (SD 1.3) \%, respectively (Fig. 5(a)). Furthermore, the dihydriethidium assay (Fig. 5(b)) showed that glyceollins also remarkably inhibited superoxide anion production stimulated by PDGF. These results indicate that

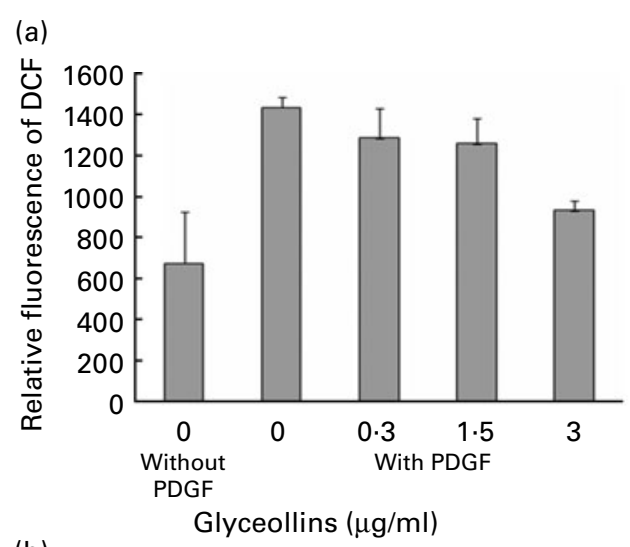

(b)
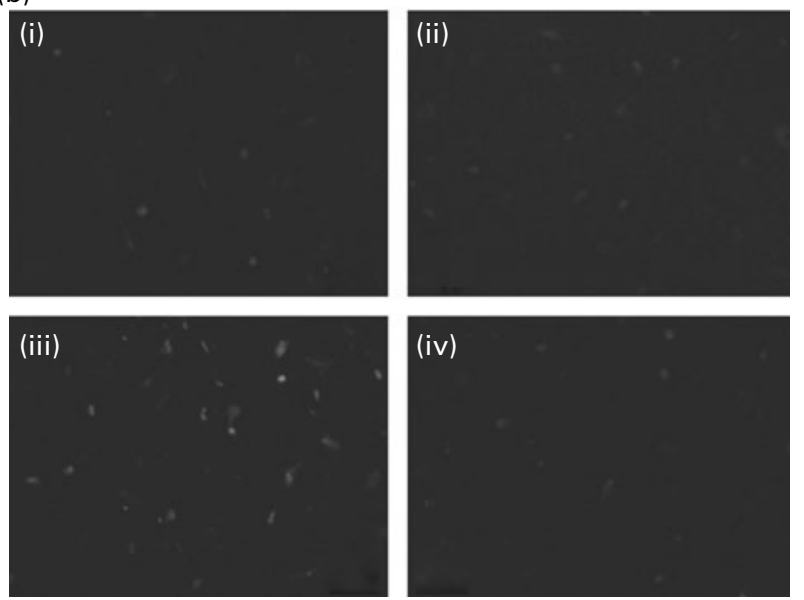

Fig. 5. Effects of glyceollins on platelet-derived growth factor (PDGF)stimulated reactive oxygen species production. (a) Relative fluorescence of human aortic smooth muscle cells (HASMC) stained with dichlorofluoresceindiacetate. Cells were treated with glyceollins in the presence or absence of PDGF $(20 \mathrm{ng} / \mathrm{ml})$. Values are means of six separate experiments, with standard deviations represented by vertical bars. (b) Fluorescence micrographs of HASMC stained with dihydriethidium. (i) Control; (ii) glyceollins $(3 \mu \mathrm{g} / \mathrm{ml})$; (iii) PDGF; (iv) PDGF + glyceollins $(0.3 \mu \mathrm{g} / \mathrm{ml})$. Magnification $\times 100$. glyceollins negatively regulate PDGF-increased ROS generation in VSMC.

\section{Effects of glyceollins on platelet-derived growth factor- stimulated human aortic smooth muscle cell migration}

In order to investigate the effect of glyceollins on HASMC migration, the cells were treated for $24 \mathrm{~h}$ with different concentrations of glyceollins in the presence or absence of PDGF in a Boyden chamber. The cells that migrated to the lower chamber were stained with calcein-AM, and were photographed with a fluorescence microscope. As shown in Fig. 6, treatment with glyceollins alone had no significant effect on HASMC migration compared with the DMSO-treated cells. However, PDGF significantly increased migration up to about 291.7 (SD 8) \%, while glyceollins effectively inhibited the PDGF-stimulated cell migration at $3 \mu \mathrm{g} / \mathrm{ml}$.

To confirm the effect of glyceollins on the cell migration assay, we carried out a wound healing assay, and observed the cellular morphology and migration behaviour after treatment with glyceollins. As shown in Fig. 7, glyceollins alone did not induce any change in the migration compared with control, whereas treatment with PDGF substantially promoted cell migration and cellular morphological change during the wound-healing process at the same time. However, glyceollins significantly reduced the PDGF-induced cell migration up to same level as the non-treated group.

\section{Effect of glyceollins on rearrangement of actin filaments by platelet-derived growth factor}

Since it is known that the active rearrangement of actin filaments is related to VSMC migration, we attempted to determine the effects of glyceollins in cells stimulated by PDGF-BB (Fig. 8). Treatment with glyceollins alone did not result in any change in actin microfilaments of HASMC. On the contrary, incubation with glyceollins $(3 \mu \mathrm{g} / \mathrm{ml})$ prevented the PDGF-induced loss of microfilaments, and the appearance of actin filaments looked similar in cells treated with either DMSO or glyceollins only.

\section{Discussion}

Many studies have shown anti-atherosclerotic effects by the components of various natural products such as polyphenols ${ }^{(40-42)}$ and flavonoids with antioxidant activity ${ }^{(43-45)}$. Oestrogen has been demonstrated to have anti-atherosclerotic effects $^{(46)}$. The beneficial effects of soya isoflavones, a group of natural phyto-oestrogens, on atherosclerosis have been known to be associated with oestrogenic properties. Several studies on the oestrogenic soya isoflavone genistein showed its inhibitory effects on not only the immune reaction ${ }^{(47)}$, but also the proliferation and migration of $\mathrm{VSMC}^{(48)}$. As the signalling pathway associated with VSMC, genistein inhibited smooth muscle cell proliferation through the increase in $\mathrm{p} 27^{\mathrm{kip} 1}$ in vivo ${ }^{(49)}$.

Glyceollins have been known to be de novo synthesised in raw soyabean exposed to some biotic elicitors such as fungi 

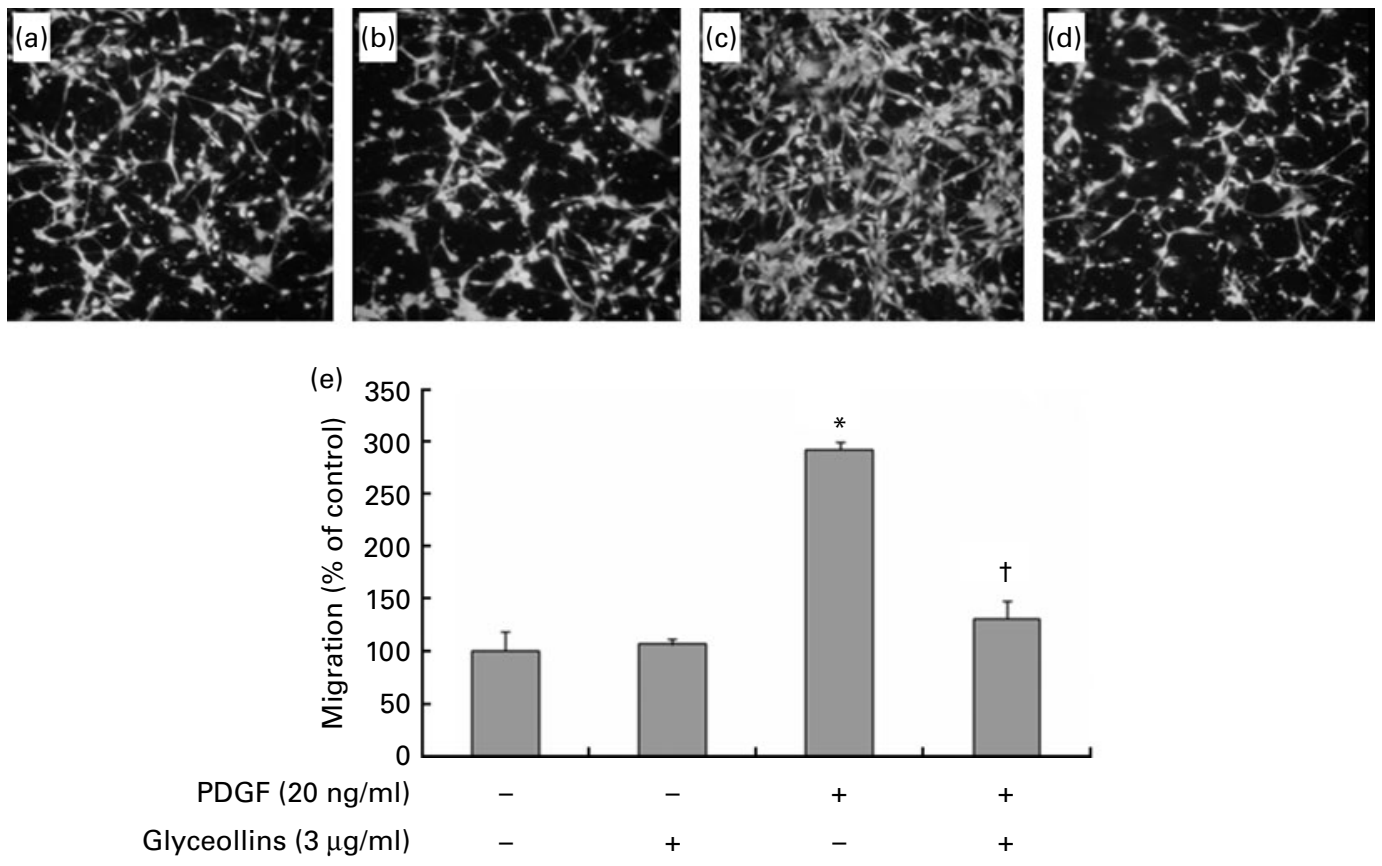

Fig. 6. Effect of glyceollins on platelet-derived growth factor (PDGF)-induced human aortic smooth muscle cell (HASMC) migration. HASMC were seeded onto the transwell plate with or without glyceollins $(3 \mu \mathrm{g} / \mathrm{ml})$ in the presence or absence of PDGF-BB $(20 \mathrm{ng} / \mathrm{ml})$ for $24 \mathrm{~h}$. Migrated HASMC were analysed with fluorescence calcein-acetoxymethyl ester (AM) staining. (a)-(d) Representative photomicrographs of the migrated cells to the lower chambers after calcein-AM staining. Magnification $\times 20$. (a) Control; (b) glyceollins $(3 \mu \mathrm{g} / \mathrm{ml})$; (c) PDGF; (d) PDGF + glyceollins $(0.3 \mu \mathrm{g} / \mathrm{ml})$. (e) Percentage of migrated cells relative to the control. Values are means of three separate experiments, with standard deviations represented by vertical bars. * Mean value was significantly different from that without PDGF and glyceollins $(P<0.05)$. † Mean value was significantly different from that with PDGF in the absence of glyceollins $(P<0.05)$.
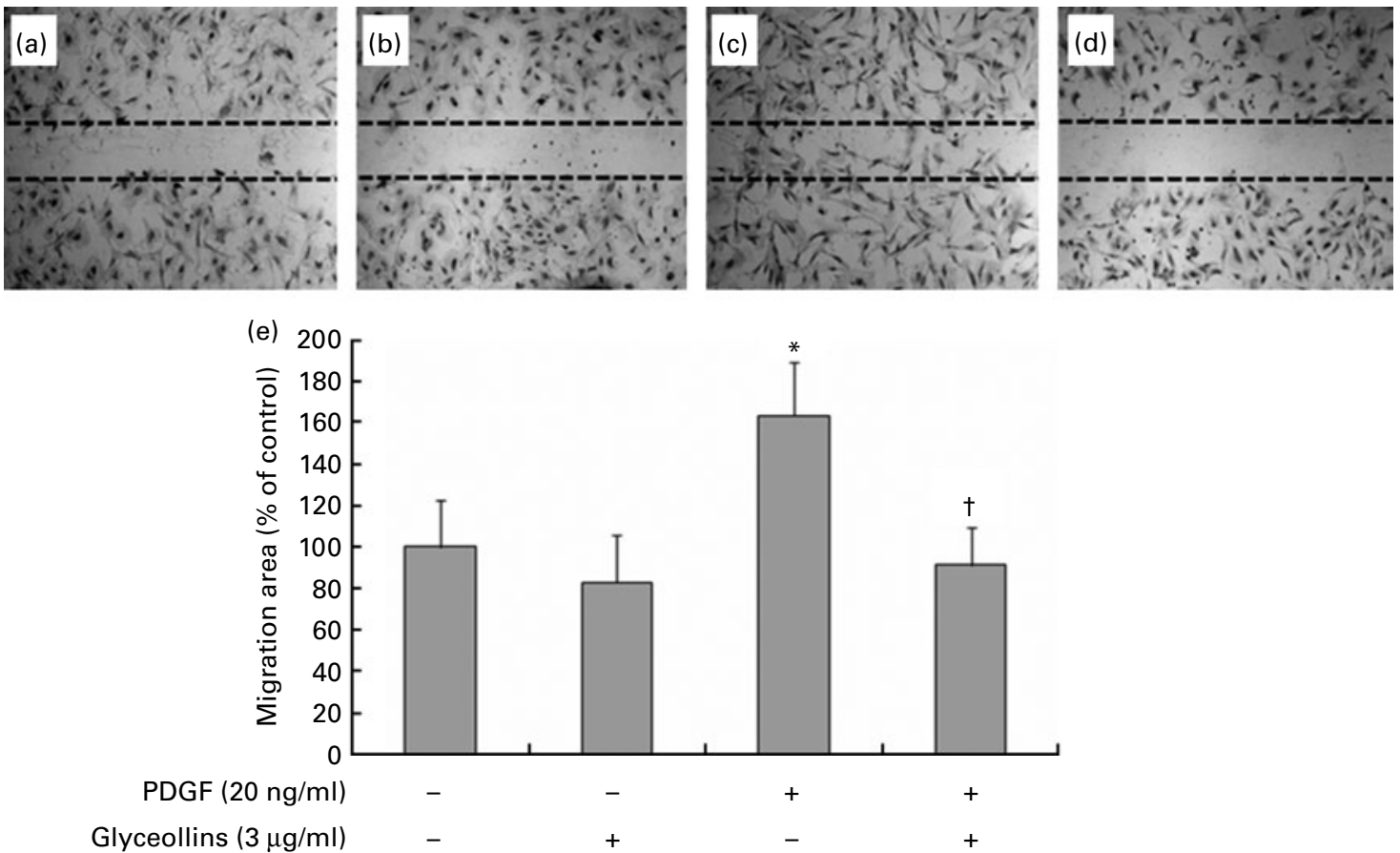

Fig. 7. Effect of glyceollins on wound healing. Confluent human aortic smooth muscle cells (HASMC) were wounded by a scratch injury line made with a sterile cell scraper. After washing, the cells were treated with or without glyceollins $(3 \mu \mathrm{g} / \mathrm{ml})$ in the presence or absence of platelet-derived growth factor (PDGF) $(20 \mathrm{ng} / \mathrm{ml})$. After incubation for $16 \mathrm{~h}$, photographs were taken $(\mathrm{a}-\mathrm{d})$. Dotted black lines delimit the initially wounded regions. Magnification $\times 20$. (a) Control; (b) glyceollins $(3 \mu \mathrm{g} / \mathrm{ml})$; (c) PDGF; (d) PDGF + glyceollins $(0.3 \mu \mathrm{g} / \mathrm{ml})$. (e) Percentage of migrated area relative to control. Values are means of three separate experiments, with standard deviations represented by vertical bars. * Mean value was significantly different from that without PDGF and glyceollins $(P<0 \cdot 05)$ † Mean value was significantly different from that with PDGF in the absence of glyceollins $(P<0.05)$. 

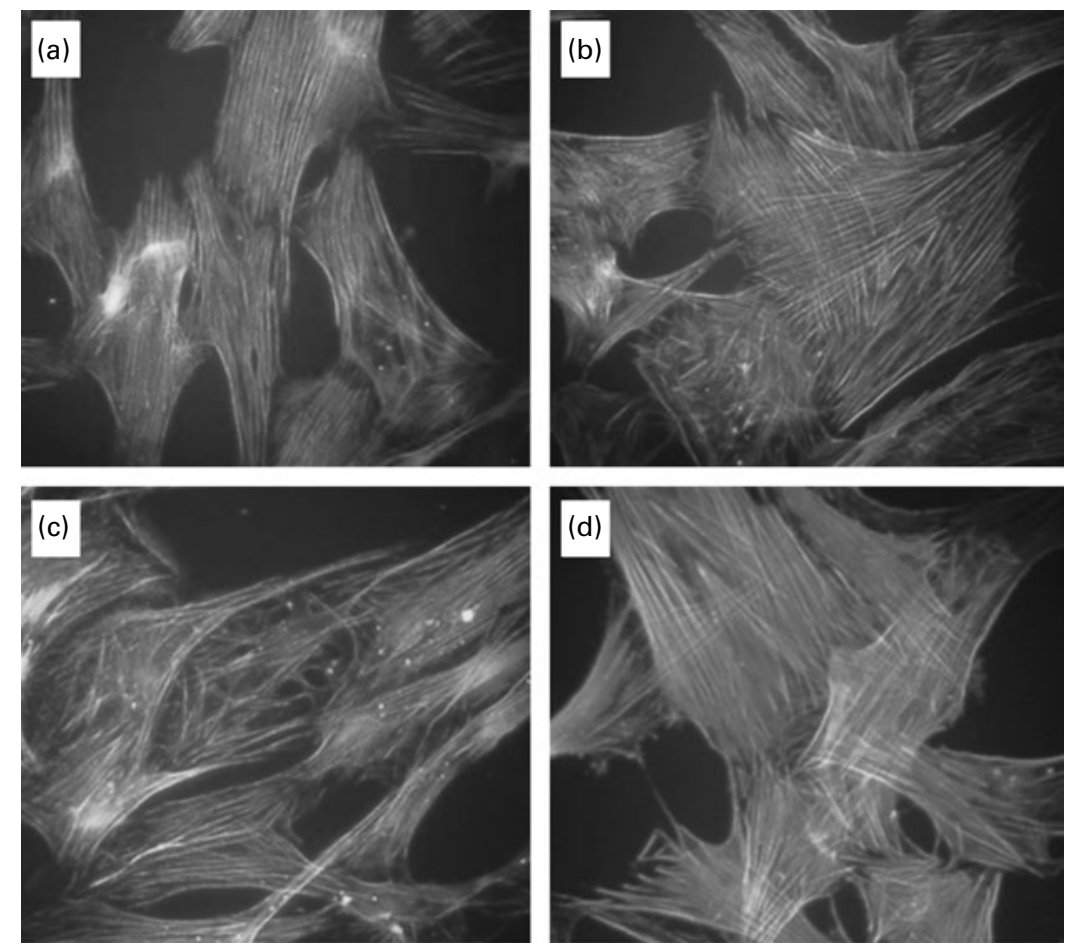

Fig. 8. Effect of glyceollins on platelet-derived growth factor (PDGF)-stimulated cytoskeletal reorganisation. The cells grown on coverslips were treated with or without glyceollins $(3 \mu \mathrm{g} / \mathrm{ml})$ in the presence or absence of PDGF-BB $(20 \mathrm{ng} / \mathrm{ml})$ for $24 \mathrm{~h}$. The cells were fixed, the actin filaments were stained with rhodamine phalloidine, and photographed using a fluorescent microscope. (a) Control; (b) glyceollins ( $3 \mu \mathrm{g} / \mathrm{ml})$; (c) PDGF; (d) PDGF + glyceollins $(0.3 \mu \mathrm{g} / \mathrm{ml})$. Magnification $\times 200$.

and have also been reported to have oestrogenic activity ${ }^{(32)}$. Our preliminary studies showed that glyceollins have antiinflammatory effects on the lipopolysaccharide-induced immune response of RAW $264 \cdot 7$ cells. Furthermore, our previous study demonstrated that the glyceollins have strong antioxidant potential in radical-scavenging activity, and inhibitory activity against singlet oxygen and lipid peroxidation. The radical-scavenging activity of glyceollins as assessed by the 2,2'-azino-bis(3-ethylbenzthiazoline-6-sulfonic acid) (ABTS) assay has been shown to be higher than daidzein but similar to genistein ${ }^{(50)}$. Considering that $84 \%$ of the mixture is glyceollin I, it is possible to speculate that glyceollin I could be the major compound for the antioxidant activity of the glyceollin mixture. Several studies also supported our presumption that glyceollin isomer I had stronger physiological activity than isomers II and $\mathrm{III}^{(51,52)}$

In the present study, we investigated the effects of glyceollins on PDGF-induced proliferation and migration of HASMC, and evaluated the mechanism of action of glyceollins. The present results demonstrated that glyceollins potently inhibited the PDGF-stimulated proliferation and DNA synthesis without cytotoxicity. The cell cycle is controlled by changes in the expression of cell cycle-regulatory proteins such as phosphorylated retinoblastoma protein (pRB), CDK, cyclins, CDK inhibitor proteins $\mathrm{p} 21^{\mathrm{cip} 1}$ and $\mathrm{p} 27^{\mathrm{kip} 1}$, and tumour suppressors including $\mathrm{p} 53^{(53-55)}$. CDK2 and $\mathrm{CDK} 4$ are key mediators during the $G_{0} / G_{1}$ to $S$ phase progression of the cell cycle and form complexes with cyclin $\mathrm{E}$ and cyclin D1, respectively. These complexes phosphorylate $\mathrm{pRB}$ and then release transcription factors that promote DNA synthesis ${ }^{(54-57)}$. The inhibitory effects of glyceollins on PDGF-induced proliferation might be due to the $G_{0} / G_{1}-S$ phase arrest, which was, in turn, mediated by reduced expression of cyclin $\mathrm{E}$ and CDK2, and increased $\mathrm{p} 27^{\mathrm{kip} 1}$ and $\mathrm{p} 53$ expressions. On the other hand, glyceollins did not have any effect on the expression of cyclin D1, CDK4 and p21 ${ }^{\mathrm{cip} 1}$ in PDGF-stimulated HASMC. Although numerous CDK are involved in the activation of $\mathrm{pRB}$, the suppression of CDK2 might be enough to inhibit the phosphorylation of $\mathrm{pRB}^{(58,59)}$. In fact, the previous study suggested that inhibition of CDK4 might not be necessary for cell cycle progression arrest ${ }^{(60,61)}$. Therefore, inhibition of $\mathrm{CDK} 2 /$ cyclin E expression may be sufficient for cell cycle arrest. This result indicates that glyceollins have influence on signal transduction events in the $G_{0} / G_{1}-S$ interphase rather than those involved in the $S-G_{2} / M$ phase.

Proliferation of VSMC plays an important role in the progression of atherosclerosis and restenosis after vascular injury and PDGF, a peptide growth factor, triggers signals for the proliferation of VSMC through the autophosphorylation of PDGFR and the interaction with cytoplasmic proteins including PLC $\gamma$, PI3K/Akt, the signal transducers and activators of transcription (STAT) family, and ROS production ${ }^{(62-64)}$. In agreement with previous studies on inhibitory effects of an antioxidant derivative, a PDGF-R $\beta$ antagonist or protein kinase inhibitor through inactivation of proteins mentioned above $^{(62-65)}$, the present study demonstrated that glyceollins reduced the activation of PDGFR- $\beta$, ERK1/2, Akt and PLC $\gamma 1$ in PDGF-stimulated HASMC. In addition, PDGF increases the 
intracellular concentration of ROS in VSMC. These effects were abolished by a ROS scavenger, resulting in a decrease in VSMC proliferation ${ }^{(38,64)} \cdot \mathrm{H}_{2} \mathrm{O}_{2}$ derived from superoxide anions can form hydroxyl radicals, and which, in turn, leads to phosphorylation of ERK1/2 and PLC $\gamma 1$ in $\mathrm{VSMC}^{(63-65)}$. It was shown that an antioxidant derivative abolished this reaction of $\mathrm{H}_{2} \mathrm{O}_{2}^{(66)}$. The present results show that glyceollins obviously inhibit the PDGF-induced production of superoxide anions as well as other ROS in HASMC, and diminish the PDGF phosphorylation of PDGFR- $\beta$, PLC $\gamma 1$, Akt and ERK. Particularly, unlike the activation of Akt by PDGF, the total Akt protein was decreased. According to a previous study, PDGF gave rise to regulated proteolytic down-regulation of Akt by PI3K and proteasome activities, resulting in controlling the activity and function of Akt in $\mathrm{VSMC}^{(67)}$. In agreement with the results from proliferation, cell cycle progression and PDGF-signal transduction mechanisms, glyceollins also blocked the PDGF-treated HASMC migration.

The purity of glyceollins isolated from a methanolic extract of $A$. sojae-inoculated sprouting soyabeans was determined to be over $95 \%$ by HPLC-mass analysis and the relative ratio of glyceollin isomers I, II and III was 12:133:1, respectively. Therefore, the biological activity observed with crude glyceollins in the study is most likely to be attributable to the glyceollins themselves.

The concentrations of glyceollin mixture used in the present study were $0.3,1.5$ and $3 \mu \mathrm{g} / \mathrm{ml}$ which are equivalent to 1,5 and $10 \mu \mathrm{M}$ (glyceollin I), unless specially indicated. The concentration of isoflavones used in most studies ranged from 16 to $500 \mu \mathrm{M}$, although some studies reported physiological activity of genistein or daidzein at doses as low as $0 \cdot 1-20 \mu \mathrm{m}^{(68,69)}$. The concentration of glyceollins used in the study is physiologically relevant because it could be readily achievable by a typical dietary intake of isoflavones in adults, and glyceollins may be better absorbed in the gastrointestinal tract due to their relatively high hydrophobicity ${ }^{(70)}$. The present results indicate that glyceollins attenuate the growth of VASMC at $0.3 \mu \mathrm{g} / \mathrm{ml}$ (about $1 \mu \mathrm{M}$-glyceollin I) under the PDGF stimulation while glyceollins at $3 \mu \mathrm{g} / \mathrm{ml}$ (about $10 \mu \mathrm{m}-$ glyceollin I) completely abrogated the effect of PDGF.

\section{Conclusion}

The present results indicate that glyceollins inhibit PDGFinduced HASMC proliferation through $G_{0} / G_{1}-S$ phase arrest by decreasing the expression of cyclin $\mathrm{E}$ and $\mathrm{CDK} 2$, and increasing the expression of $\mathrm{p} 27^{\mathrm{kip} 1}$ and $\mathrm{p} 53$. Inactivation of PDGFR- $\beta$, PLC $\gamma 1$, Akt, ERK, and reduction of ROS are presumed to be the possible mechanisms of the inhibitory effects of glyceollins. In addition to anti-proliferative effects, glyceollins have an anti-migrative effect on PDGF-stimulated HASMC. This property of glyceollins may play an important role for the beneficial effects on CVD and angioplasty.

\section{Acknowledgements}

This research was supported by the Basic Science Research Program through the National Research Foundation of Korea
(NRF) funded by the Ministry of Education, Science and Technology (no. 2010-0009928 and 2010-0027204).

H. J. K. and B.-Y. C. contributed equally as corresponding author to the study.

J. S. K. and J.-T. W. planned the study. H. J. K. and B.-Y. C. performed the proliferation, Western blotting, migration, wound healing, and cytoskeletal reorganisation assay. B. C. and J. S. L. performed the ROS and flow cytometric analysis. H. J. K., B.-Y C. and J.-S. K. wrote the manuscript.

The authors have declared no conflict of interest.

\section{References}

1. Ross R (1993) The pathogenesis of atherosclerosis: a perspective for the 1990s. Nature 362, 801-809.

2. Raines EW (2004) PDGF and cardiovascular disease. Cytokine Growth Factor Rev 5, 237-254.

3. Jiang B, Yamamura S, Nelson PR, et al. (1996) Differential effects of platelet-derived growth factor isotypes on human smooth muscle cell proliferation and migration are mediated by distinct signaling pathways. Surgery 120, 427-431.

4. Koyama N, Hart CE \& Clowes AW (1994) Different functions of the platelet-derived growth factor- $\alpha$ and $-\beta$ receptors for the migration and proliferation of cultured baboon smooth muscle cells. Circ Res 75, 682-691.

5. Sirois MG, Simons M \& Edelman ER (1997) Antisense oligonucleotide inhibition of PDGFR- $\beta$ receptor subunit expression directs suppression of intimal thickening. Circulation 95, 669-676.

6. Jawien A, Bowen-Pope DF, Lindner V, et al. (1992) Plateletderived growth factor promotes smooth muscle migration and intimal thickening in a rat model of balloon angioplasty. $J$ Clin Invest 89, 507-511.

7. Banai S (1998) PDGF-receptor tyrosine kinase blocker AG1295 selectively attenuates smooth muscle cell growth in vitro and reduces neointimal formation after balloon angioplasty in swine. Circulation 97, 1960-1969.

8. Bornfeldt KE, Raines EW, Nakano T, et al. (1994) Insulin-like growth factor-I and platelet-derived growth factor-BB induce directed migration of human arterial smooth muscle cells via signaling pathways that are distinct from those of proliferation. J Clin Invest 93, 1266-1274.

9. Bornfeldt KE, Raines EW, Graves LM, et al. (1995) Plateletderived growth factor. Distinct signal transduction pathways associated with migration versus proliferation. Ann N Y Acad Sci 766, 416-430.

10. Sundaresan M, Yu ZX, Ferrans VJ, et al. (1995) Requirement for generation of $\mathrm{H}_{2} \mathrm{O}_{2}$ for platelet-derived growth factor signal transduction. Science 270, 296-299.

11. Lephart ED, West TW, Weber KS, et al. (2002) Neurobehavioral effects of dietary soy phytoestrogens. Neurotoxicol Teratol 24, 5-16.

12. Lund TD, West TW, Tian LY, et al. (2001) Visual spatial memory is enhanced in female rats (but inhibited in males) by dietary soy phytoestrogens. BMC Neurosci 2, 20.

13. Nagata C, Shimizu H, Takami R, et al. (1999) Hot flushes and other menopausal symptoms in relation to soy product intake in Japanese women. Climacteric 2, 6-12.

14. Nagata C, Takatsuka N, Kawakami N, et al. (2001) Soy product intake and hot flashes in Japanese women: results from a community-based prospective study. Am J Epidemiol 153, 790-793.

15. Anderson JJ \& Garner SC (1998) Phytoestrogens and bone. Ball Clin Endocrinol Metabiol 12, 543-557. 
16. Lichtenstein A (1998) Soy protein, isoflavones and cardiovascular disease risk. J Nutr 128, 1589-1592.

17. Wiseman H, O'Reilly JD, Adlercreutz H, et al. (2000) Isoflavone phytoestrogens consumed in soy decrease $\mathrm{F}_{2}$-isoprostane concentrations and increase resistance of low-density lipoprotein to oxidation in humans. Am J Clin Nutr 72, 395-400.

18. Mortensen A, Kulling SE, Schwartz H, et al. (2009) Analytical and compositional aspects of isoflavones in food and their biological effects. Mol Nutr Food Res 53, 266-309.

19. Zava DT \& Duwe G (1997) Estrogenic and antiproliferative properties of genistein and other flavonoids in human breast cancer cells in vitro. Nutr Cancer 27, 31-40.

20. Davis JN, Singh B, Bhuiyan M, et al. (1998) Genisteininduced upregulation of p21WAFI, downregulation of cyclin b, and induction of apoptosis in prostate cancer cells. Nutr Cancer 32, 123-131.

21. Onozawa M, Fukada K, Ohthani M, et al. (1998) Effects of soybean isoflavones on cell growth and apoptosis of the human prostatic cancer cell line LNCaP. Jpn J Clin Oncol 28, 360-363.

22. Dubey RK, Gillespie DG, Imthurn B, et al. (1999) Phytoestrogens inhibit growth and MAP kinase activity in human aortic smooth muscle cells. Hypertension 33, 177-182.

23. Pignatelli P, Pulcinelli FM, Lenti L, et al. (1998) Hydrogen peroxide is involved in collagen-induced platelet activation. Blood 91, 484-490.

24. Davis JN, Kucuk O, Djuric Z, et al. (2001) Soy isoflavone supplementation in healthy men prevents NF- $\mathrm{B}$ activation by TNF- $\alpha$ in blood lymphocytes. Free Radic Biol Med 30, 1293-1302.

25. Satake N \& Shibata S (1999) The potentiating effect of genistein on the relaxation induced by isoproterenol in rat aortic rings. Gen Pharmacol 33, 221-227.

26. Weber C, Negrescu E, Erl W, et al. (1995) Inhibitors of protein tyrosine kinase suppress TNF-stimulated induction of endothelial cell adhesion molecules. J Immunol 155, 445-451.

27. Gottstein N, Ewins BA, Eccleston C, et al. (2003) Effect of genistein and daidzein on platelet aggregation and monocyte and endothelial function. Br J Nutr 89, 607-616.

28. Payton-Stewart F, Schoene NW, Kim YS, et al. (2009) Molecular effects of soy phytoalexin glyceollins in human prostate cancer cells LNCaP. Mol Carcinog 48, 862-871.

29. Salvo VA (2006) Antiestrogenic glyceollins suppress human breast and ovarian carcinoma tumorigenesis. Clin Cancer Res 12, 7159-7164.

30. Brent KJ \& Hollomon DW (1998) Fungicide Resistance: The Assessment of Risk. Monograph No. 2. Brussels: Global Crop Protection Federation.

31. Costa TR, Fernandes FLF, Santos SC, et al. (2000) Antifungal activity of volatile constituents of Eugenia dysenterica leaf oil. J Ethnopharmcol 72, 111-117.

32. Kim HJ, Suh HJ, Kim JH, et al. (2010) Estrogenic activity of glyceollins isolated from soybean elicited with Aspergillus sojae. J Med Food 13, 382-390.

33. Cha BY, Shi WL, Yonezawa T, et al. (2009) An inhibitory effect of chrysoeriol on platelet-derived growth factor (PDGF)-induced proliferation and PDGF receptor signaling in human aortic smooth muscle cells. J Pharmacol Sci $\mathbf{1 1 0}$ $105-110$

34. Erl W (2000) Pyrrolidine dithiocarbamate-induced apoptosis depends on cell type, density, and the presence of $\mathrm{Cu}^{2+}$ and $\mathrm{Zn}^{2+}$. Am J Physiol Cell Physiol 278, 1116-1125.

35. Mu H, Ohashi R, Yang S, et al. (2006) Thymosin beta10 inhibits cell migration and capillary-like tube formation of human coronary artery endothelial cells. Cell Motil Cytoskeleton 63, 222-230.

36. Wang H \& Joseph JA (1999) Quantifying cellular oxidative stress by dichlorofluorescein assay using microplate reader. Free Radic Biol Med 27, 612-616.

37. Li W, Miller F, Brown M, et al. (2000) Enhanced $\mathrm{H}_{2} \mathrm{O}_{2^{-}}$ induced cytotoxicity in "epithelioid" smooth muscle cells: implications for neointimal regression. Arterioscler Thromb Vasc Biol 20, 1473-1479.

38. Wedgwood S \& Black SM (2004) Combined superoxide dismutase/catalase mimetics alter fetal pulmonary arterial smooth muscle cell growth. Antioxid Redox Signal 6, 191-197.

39. Parinandi NL, Kleinberg MA, Usatyuk PV, et al. (2003) Hyperoxia-induced NAD(P)H oxidase activation and regulation by MAP kinases in human lung endothelial cells. $\mathrm{Am}$ J Physiol Lung Cell Mol Physiol 284, 26-38.

40. Arts IC \& Hollman PC (2005) Polyphenols and disease risk in epidemiologic studies. Am J Clin Nutr 81, Suppl. 1, 317S-325S.

41. Stangl V, Dreger H, Stangl K, et al. (2007) Molecular targets of tea polyphenols in the cardiovascular system. Cardiovasc Res 73, 348-358.

42. Heber D (2001) Herbs and atherosclerosis. Curr Atheroscler Rep 3, 93-96.

43. Kim TJ, Zhang YH, Kim Y, et al. (2002) Effects of apigenin on the serum- and platelet derived growth factor-BB-induced proliferation of rat aortic vascular smooth muscle cells. Planta Med 68, 605-609.

44. Rosenkranz S, Knirel D, Dietrich H, et al. (2002) Inhibition of the PDGF receptor by red wine flavonoids provides a molecular explanation for the "French paradox". FASEB J 16, 1958-1960

45. Miller NJ \& Ruiz-Larrea MB (2002) Flavonoids and other plant phenols in the diet: their significance as antioxidants. J Nutr Environ Med 12, 39-51.

46. Jiang P, Liu J, Li W, et al. (2010) Role of p53 and p21 polymorphisms in the risk of cervical cancer among Chinese women. Acta Biochim Biophys Sin (Shanghai) 42, 671-676.

47. Sosroseno W, Bird PS \& Seymour GJ (2003) Intracellular proteins involved in Porphyromonas gingivalis-induced opsonophagocytic activities of a murine macrophage cell line (RAW264.7 cells). J Microbiol Immunol Infect 36, 229-235.

48. Pan W, Ikeda K, Takebe M, et al. (2001) Genistein, daidzein and glycitein inhibit growth and DNA synthesis of aortic smooth muscle cells from stroke-prone spontaneously hypertensive rats. J Nutr 131, 1154-1158.

49. Yu JY, Lee JJ, Lim Y, et al. (2008) Genistein inhibits rat aortic smooth muscle cell proliferation through the induction of p2 $7^{\mathrm{kip} 1}$. J Pharmacol Sci 107, 90-98.

50. Kim HJ, Suh HJ, Kim JH, et al. (2010) Antioxidant activity of glyceollins derived from soybean elicited with Aspergillus sojae. J Agric Food Chem 24, 11633-11638.

51. Zimmermann MC, Tilghman SL, Boué SM, et al. (2010) Glyceollin I, a novel antiestrogenic phytoalexin isolated from activated soy. J Pharmacol Exp Ther 332, 35-45.

52. Payton-Stewart F, Khupse RS, Boué SM, et al. (2010) Glyceollin I enantiomers distinctly regulate ER-mediated gene expression. Steroids 75, 870-878.

53. Braun-Dullaeus RC, Mann MJ, Sedding DG, et al. (2004) Cell cycle-dependent regulation of smooth muscle cell activation. Arterioscler Thromb Vasc Biol 24, 845-850.

54. Sherr CJ (1996) Cancer cell cycles. Science 274, 1672-1677.

55. Sherr CJ \& Roberts JM (1999) CDK inhibitors: positive and negative regulators of G1-phase progression. Genes Dev 13, 1501-1512. 
56. Jirawatnotai S, Aziyu A, Osmundson EC, et al. (2004) Cdk4 is indispensable for postnatal proliferation of the anterior pituitary. J Biol Chem 279, 51100-51106.

57. Martin A, Odajima J, Hunt SL, et al. (2005) Cdk2 is dispensable for cell cycle inhibition and tumor suppression mediated by $\mathrm{p} 27^{\mathrm{Kip} 1}$ and $\mathrm{p} 21^{\mathrm{Cip} 1}$. Cancer Cell 7, 591-598.

58. Akiyama T, Ohuchi T, Sumida S, et al. (1992) Phosphorylation of retinoblastoma protein by CDK2. Proc Natl Acad Sci U S A 89, 7900-7904.

59. Connell-Crowley L, Elledge SJ \& Harper JW (1998) $G_{1}$ cyclin dependent kinases are sufficient to initiate DNA synthesis in quiescent human fibroblast. Curr Biol 8, 65-68.

60. Brooks EE, Gray NS, Joly A, et al. (1997) CVT-313, a specific and potent inhibitor of CDK2 that prevents neointimal proliferation. J Biol Chem 272, 29207-29211.

61. Sasaguri T, Ishida A, Kosaka C, et al. (1996) Phorbolester inhibits the phosphorylation of the retinoblastoma protein without suppressing cyclin D-associated kinase in vascular smooth muscle cells. J Biol Chem 271, 8345-8351.

62. Heldin CH \& Westermark B (1999) Mechanism of action and in vivo role of platelet-derived growth factor. Physiol Rev 79, 1283-1316.

63. Brown DI \& Griendling KK (2009) Nox proteins in signal transduction. Free Radic Biol Med 47, 1239-1253.

64. Sundaresan M, Yu ZX, Ferrans VJ, et al. (1995) Requirement for generation of $\mathrm{H}_{2} \mathrm{O}_{2}$ for platelet-derived growth factor signal transduction. Science 270, 296-299.
65. Choi MH, Lee IK, Kim GW, et al. (2005) Regulation of PDGF signalling and vascular remodelling by peroxiredoxin II. Nature 435, 347-353.

66. Hsieh CY, Liu CL, Hsu MJ, et al. (2010) Inhibition of vascular smooth muscle cell proliferation by the vitamin E derivative pentamethylhydroxychromane in an in vitro and in vivo study: pivotal role of hydroxyl radical-mediated PLC $\gamma 1$ and JAK2 phosphorylation. Free Radic Biol Med 49, 8881-8893.

67. Adachi M, Katsumura KR, Fujii K, et al. (2003) Proteasomedependent decrease in Akt by growth factors in vascular smooth muscle cells. FEBS Lett 554, 77-80.

68. Chen XW, Garner SC \& Anderson JJB (2002) Isoflavones regulate interleukin- 6 and osteoprotegerin synthesis during osteoblast cell differentiation via an estrogen-receptordependent pathway. Biochem Biophys Res Commun 295, 417-422.

69. Chacko BK, Chandler RT, Mundhekar A, et al. (2005) Revealing anti-inflammatory mechanisms of soy isoflavones by flow: modulation of leukocyte-endothelial cell interactions. Am J Physiol Heart Circ Physiol 289, 908-915.

70. Arai Y, Uehara M, Sato Y, et al. (2000) Comparison of isoflavones among dietary intake, plasma concentration and urinary excretion for accurate estimation of phytoestrogen intake. J Epidemiol 10, 127-135. 